\title{
Land tenure security and technical efficiency: new insights from a case study in Northwest China
}

\section{XIANLEI MA}

China Centre for Land Policy Research \& College of Public Anministration, Nanjing Agricultural University, China.

Email:maxianlei@njau.edu.cn

\section{NICO HEERINK}

Department of Social Sciences, Wageningen University, The Netherlands; China Centre for Land Policy Research \& College of Public Administration, Nanjing Agricultural University, China; College of Public Administration, Zhejiang University, China.

Email:nico.heerink@wur.nl

\section{SHUYI FENG}

China Centre for Land Policy Research \& College of Public Administration, Nanjing Agricultural University, China.

Email:shuyifeng@njau.edu.cn

\section{XIAOPING SHI}

China Centre for Land Policy Research \& College of Public Administration, Nanjing Agricultural University, No.6, Tongwei Road, Nanjing, Jiangsu, China, 210095.

Tel: $+86(0) 2584395078$.

Email: serena2@njau.edu.cn

Submitted 20 January 2014; revised 29 April 2015, 1 September 2015, 8 April 2016; accepted 19 October 2016; first published online 1 February 2017

ABSTRACT. Improving technical efficiency in agriculture can play an important role in meeting present and future demands for agricultural products, at the same time enhancing the long-term sustainability of land and water use. This paper examines the impact

Financial support for the research was provided by the National Natural Science Foundation of China $(71373127,71573134,71322301)$ and by the Programme Strategic Scientific Alliances of the Royal Netherlands Academy of Arts and Sciences (KNAW) and the Ministry of Science and Technology, P.R. China. 
of household perceptions of land tenure security on technical efficiency using detailed household-level data collected in Minle County in northwest China. The authors find that the (perceived) tenure security provided by land certificates encourages part-time farming with relatively low technical efficiency. The renting out of land by households with migrant members can only partly make up for this negative effect, because land rental markets are thin and highly fragmented. Therefore, the provision of land certificates to rural households has a negative impact on technical efficiency. For tenure security provided by the expected absence of land reallocations in the near future, on the other hand, the authors find that it reduces temporary migration and thereby contributes to higher technical efficiency.

\section{Introduction}

Agricultural growth has received renewed attention in recent years as a means of poverty alleviation and an increase in welfare in developing countries. (e.g., World Bank, 2007). An important element of agriculturebased growth policies is promoting the productive and efficient use of land and water resources in order to meet present and future demands for agricultural products, while ensuring the long-term sustainability of the land and water quantity and quality.

Secure land property rights are considered an important catalyst for agricultural growth and sustainable resource use, and thus the relationship between land tenure security and agricultural productivity has received much attention in the existing literature. Studies based on Asian experiences suggest a positive, but small in magnitude, effect of land tenure security on productivity (Feder, 1988; Jacoby et al., 2002). Some studies on Uganda and Ethiopia find that tenure security has a positive impact on productivity (Deininger and Jin, 2006; Deininger et al., 2008), whereas other studies on the same two countries find no evidence of productivity differences across different bundles of land rights (Gavian and Ehui, 1999; Pender et al., 2004). These ambiguous results can probably be related to the local context and the overarching macro and sectoral conditions within which tenure systems operate (Place, 2009).

Theories available suggest that secure property rights to land are likely to raise investments and the use of farm inputs by reducing the risk of investments and/or increasing capital availability (Feder, 1988). The existing empirical literature, therefore, focuses mainly on the productionenhancing effect of land investments and increased input use levels caused by improved tenure security (e.g., Jacoby et al., 2002). Two other effects distinguished in the literature have received less attention in empirical studies so far. The first effect is the so-called land market effect. Land rental markets can transfer land to more efficient farmers, i.e., farmers who are able to obtain higher quantities of output from the same levels of inputs used in production. It is also termed the factor equalization effect. The second effect is the migration effect. Improved land tenure security can induce household participation in rural-urban migration (Mullan et al., 2011), which might contribute to less efficient farm management practices of households with one or more migrated members. The land market effect is expected to raise agricultural production, just like the investment and input effects, while the migration effect will generally lower it. More empirical research 
is needed on the latter two effects in order to obtain a better understanding of the full impact of land tenure security on agricultural production.

The choice of the dependent variable may greatly affect the results obtained in empirical studies of the impact of tenure security, and partly explain the mixed findings obtained so far. One group of studies uses land productivity, defined as total output divided by land size (e.g., Chand and Yala, 2009; Place, 2009). Land productivity is especially relevant for examining intensive agricultural systems in land-scarce countries (e.g., China, Ethiopia and Uganda). It is a partial measure of productivity, focusing on land input and ignoring other factors of production and inputs. A second group of studies uses total factor productivity (TFP), defined as the ratio of agricultural output to an index of all inputs used in production (e.g., Chen et al., 2008). TFP is commonly used to measure technical progress. Lastly, a third group of studies uses technical efficiency (TE), which measures the amount of output obtained from a given amount of inputs, compared to the maximum output that can be derived under best practices from these inputs (e.g., Ahmed et al., 2002; Tan et al., 2010).

Another important choice is that of the land rights indicator. The existing literature in this field mainly focuses on the impact of formal land rights (legal land tenure) derived from land laws and regulations, land certification and tenancy status (Feng, 2008; Zhang et al., 2011). However, it is household perceptions of their land rights (that is, perceived land tenure) that impact directly on household decisions with respect to land investments, input use, participation in land rental markets and migration. In the case of rural China, legal land tenure security has been enhanced by market-oriented land tenure reforms initiated by the Chinese government since 1998 (Ma et al., 2015), but household perceptions of land tenure may not be as secure as dictated by the legal tenure reforms. This may be caused by the local implementation of legal land tenure regulations, such as land certificates that specify the land area assigned to a household but not the plot boundaries. Even when the local implementation is similar, perceptions of land rights security may vary across households. Differences in tenure security perceptions may therefore be an important explanatory factor of observed differences in productivity and TE. Yet, the relationships are currently not well understood and more empirical research is needed in order to gain more insights into the role of perceived tenure security in promoting (or reducing) productivity and TE.

The main objective of this paper is to examine the effect of perceived land tenure security on TE in rural China. We focus on the land rental market effect and the migration effect of tenure security by controlling for (investments in) land quality and variable input use in the empirical analysis. A cross-section data set, containing household-level data on agricultural production, tenure security and other relevant factors, is used to estimate TE and its determinants. The data were collected among 312 households in 21 villages in Minle County, Gansu Province, northwest China. Given the prevailing problems with the sustainable use of land and water resources in China's intensive agricultural system (e.g., Qu et al., 2011), and given China's national policy goal of being self-sufficient in grain production, the insights obtained from this study may provide an important input 
into the development of science-based policies for sustainable agricultural development and rural poverty reduction in China.

This paper contributes to the scientific literature on the effect of land tenure security on productivity by simultaneously: (i) focusing on the land rental market effect and migration effect of land tenure security, while controlling for the investment and input effects that are usually examined in the existing literature; (ii) examining the effect of land tenure security on TE instead of land productivity; and (iii) examining the role of tenure security as perceived by rural households instead of formal tenure security as specified in land laws and land titling.

The paper is organized as follows. Section 2 presents the conceptual model which links land tenure security to TE and agricultural production growth. Section 3 specifies the model that we use for the empirical analysis and the strategy that we apply for estimating the model. This is followed by an introduction of the data set and the variables used in the empirical analysis in section 4 . Section 5 reports and discusses the estimation results. The paper ends with concluding remarks in section 6 .

\section{Conceptual model}

Feder (1988) developed a seminal conceptual model linking land tenure and agricultural production growth in Thai agriculture. This model has subsequently been used by many economists to test for linkages between tenure security, investment and productivity, as well as the impact of promoting land market development and other policy instruments (Place, 2009). Three important economic relationships between land titles and agricultural production growth are included in Feder's model: (1) land title can be used as collateral to improve access to credit for agricultural investment; (2) title can increase security of tenure and enhance farmers' willingness to make medium and long-term investments; and (3) title may stimulate land markets that will facilitate the transfer of land resources to more productive farmers. One important modification of Feder's model is the impact that investments in land may have on enhancing tenure security, leading to a bidirectional link between the two (Besley, 1995; Jacoby et al., 2002).

Another influential conceptual economic model linking land tenure and agricultural production growth was developed by Place (2009). It stipulates that the privatization of land rights can increase investments in agriculture and the purchase of variable inputs, and thereby increase productivity. Feder's (1988) model does not consider that higher tenure security may increase the use of variable inputs (e.g., fertilizers or labor). Place's (2009) model, on the other hand, ignores the factor equalization effect of land markets. Neither model takes into account the potential impact of land tenure security on rural-urban migration (Mullan et al., 2011; Ma et al., 2016), and its consequences for productivity and TE. Figure 1 presents a more comprehensive conceptual model of the household-level effects of perceived tenure security on agricultural production growth in China. ${ }^{1}$ Agricultural

${ }^{1}$ Potential feedback mechanisms, like the impact of investments in land quality on tenure security, are omitted for simplicity. 


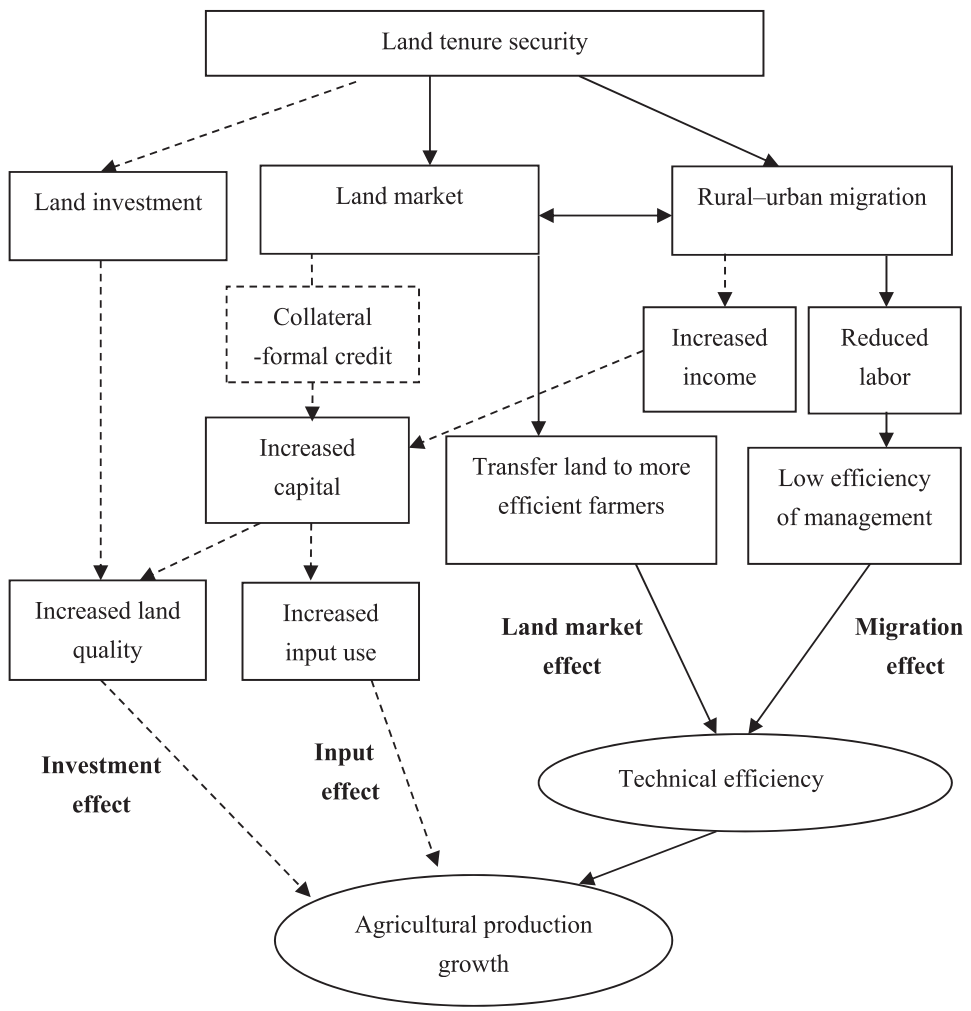

Figure 1. Conceptual framework (household level)

Notes: Dashed arrows show the paths of the investment and input effects, while solid arrows show the paths of the land market and migration effects. The dashed square indicates that land is not allowed to be used as collateral in China. Only the solid arrows are examined in this study.

production growth in the model is a result of land investments (investment effect), increased use of variable inputs (input effect), transferring land to more productive farmers (land market effect), and less efficient agricultural management practices resulting from rural-urban migration (migration effect). The investment effect and input effect directly affect agricultural production (depicted by dashed arrows in figure 1), while the land market effect and migration effect have an indirect impact that goes through TE (depicted by solid arrows in figure 1).

The investment effect indicates that more secure tenure increases longterm land investments. Land investments, such as tree planting, terracing, green manure plantation, organic application, well-digging, land leveling, surface irrigation, drainage and terracing, can improve soil quality and thereby increase agricultural production in the long term. Secure property rights may reduce the risks involved in making such long-term investments. This effect has been widely discussed and examined (e.g., Besley, 1995). However, the aim of some long-term land investments may 
be to enhance tenure security rather than to increase land quality and agricultural production (Brasselle et al., 2002). It should also be noted that more secure tenure may indirectly affect land investments by the increased capital availability resulting from improved credit market access (see figure 1).

The input effect refers to increased use of variable inputs, such as seed, water, chemical fertilizers, pesticides and herbicides. Secure land can be used as collateral to improve access to credit when land sales markets exist; increased availability of credit may stimulate the purchase of variable inputs (Feder, 1988). This effect is also called the collateralizability effect. In China, however, land is not allowed to be used as collateral under current laws and regulations. Yet, more secure property rights can affect input use in an indirect way by stimulating rural-urban migration (Mullan et al., 2011). Remittances sent home by migrants increase household incomes, and thereby the available capital for purchase of inputs (Rozelle et al., 1999). ${ }^{2}$ Hence, increased tenure security may affect variable input use because it increases migrant remittances, rather than access to formal credit, in rural China (see figure 1).

The land market effect refers to transferring land to more efficient farmers. Increased land tenure security stimulates land market development (e.g., Deininger and Zegarra, 2003). In the case of absent or thin agricultural labor markets, the land rental market often plays an important role in enhancing productivity and TE as it allows land transfers from less productive to more productive producers.

The migration effect on TE refers to changing agricultural production and management modes of rural households with one or more migrant members. Increased tenure security may stimulate temporary migration (e.g., Ma et al., 2016). ${ }^{3}$ Temporary migration in its turn can reduce the efficiency of farm management practices, especially when the hiring of agricultural labor to replace family labor incurs prohibitively large transaction costs or when hired labor is not as efficient as family labor (Feng et al., 2010; Shi et al., 2011). An example is the application of large quantities of fertilizers or water at the time of planting or sowing by temporary migrating households, instead of more efficient applications that are spread over time and depend on the requirements for plant growth. It should be noted, however, that improved tenure security may not stimulate migration if households have few options to rent out their land to others. In such cases, a decrease in the probability of land expropriation implies that a household will retain more land, which needs farm labor; it may thereby decrease migration incentives (Mullan et al., 2011). In other

${ }^{2}$ Rural-urban migration may also affect input use when non-labor inputs are complementary to, or substitutes for, labor in agricultural production. This relationship is not shown in the figure for reasons of simplicity.

${ }^{3}$ Chernina et al. (2014) find that the 1906 land reform in Russia stimulated permanent migration by improving the liquidity of land. Since rural households could not sell their land rights or use them as collateral in China at the time of our survey, we neglect the land liquidity effect in this study. 
words, although the migration effect on TE from improved tenure security is generally negative, it may also be positive if improved tenure security reduces migration incentives. We will come back to this issue in section 5.3.

In the empirical model that we apply in this paper, land investments (as reflected in land quality) and variable inputs are used as control variables in explaining agricultural production. The observed effect of land tenure security on agricultural production therefore reflects the net impact of the other two effects: the (positive) land market effect and the (generally negative) migration effect. Its overall impact depends on the magnitude of the land market effect and migration effect (see figure 1).

In the context of well-functioning land rental and labor markets, the net effect of land tenure security on TE is expected to be positive. More secure tenure will induce the transfer of land from low-productive households to high-productive households, while low-productive households will shift from agriculture to non-agricultural sectors, and in many cases migrate permanently to urban areas. Hence, the migration effect is expected to be (close to) zero, while the land market effect will be positive.

However, major bottlenecks still limit the functioning of the land rental and labor market in China. The current rural land rental market is highly segmented. The majority of land transfers take place within villages and usually between households that are related through kinship. This seriously limits the transfer of land to high-productive households. The current hukou (household registration) system limits the number of labor migrants who take their families with them and migrate permanently. The lack of social security and the relatively expensive access to housing and health and education facilities in urban areas for migrants with a rural hukou mean that many labor migrants leave their families behind and eventually return to their home villages (Whalley and Zhang, 2007). This short-duration, individual migration contributes to part-time farming which will often have a relatively low TE. The observed overall effect of land tenure security on TE may therefore even be negative.

\section{Model choice and estimation strategy}

\subsection{Model choice}

Technical efficiency is estimated in our study by using a stochastic production frontier. The approach imposes an explicit and possibly restrictive functional form on the technology. However, it permits the estimation of determinants of inefficiency of households. The stochastic frontier model has been used, among others, to examine the effect of land rental and offfarm employment, land fragmentation, land reallocation and land tenure contracts on TE in China and elsewhere (e.g., Ahmed et al., 2002; Feng, 2008; Tan et al., 2010; Zhang et al., 2011).

The stochastic frontier model assumes an error term with two additive components - an idiosyncratic (two-sided) component, which accounts for pure random factors, and a one-sided component, which captures the effects of inefficiency relative to the stochastic frontier.

Following recent studies (e.g., Tan et al., 2010; Zhang et al., 2011), we use a translog specification for the production frontier. The estimable form is 
specified as:

$$
\begin{aligned}
\ln \left(Y_{i}\right)= & \beta_{0}+\sum_{j=1}^{n} \beta_{j} \ln \left(X_{j i}\right)+\frac{1}{2} \sum_{j=1}^{n} \sum_{k=1}^{n} \beta_{j k} \ln \left(X_{j i}\right) \ln \left(X_{k i}\right) \\
& +\delta C_{i}+\vartheta_{i}-\mu_{i} \\
\mathrm{TE}_{i}= & \theta_{0}+\theta M_{i},
\end{aligned}
$$

where $n$ denotes the number of inputs, $X_{j i}$ denotes the quantity of input $j$ used for crop production by household $i, C_{i}$ is a vector of other variables that may affect agricultural output, $\vartheta_{i}$ and $\mu_{i}$ account for pure random factors and technical inefficiency, respectively, $\beta_{0}, \beta_{j}, \beta_{j k}$ and $\delta$ are unknown coefficients; $\mathrm{TE}_{i}$ is technical efficiency, which is defined as $\mathrm{TE}_{i}=\exp \left(-\mu_{i}\right)$; $M_{i}$ is a vector denoting land tenure security and other factors affecting technical efficiency, and $\theta_{0}$ and $\theta$ are unknown coefficients.

\subsection{Estimation strategy}

The stochastic frontier model can be estimated using either one-step or two-step approaches. In the two-step procedure, the frontier production function (equation (1)) and the efficiency levels are estimated first, ignoring the farm-specific variables that affect TE only. In the second step, TE is regressed against these explanatory variables (equation (2)). The two-stage procedure has been shown to yield inconsistent estimates of the parameters as well as TE because TE may be correlated with input levels (Kumbhakar et al., 1991: 279-280). Moreover, the estimated micro-level efficiencies in a two-step procedure are spuriously underdispersed, even when there is no correlation between factors affecting TE and production inputs (Wang and Schmidt, 2002). The solution to these problems is the application of a onestep maximum likelihood procedure in which, at given levels of input use, the assumed relationship between the farm-specific driving factor(s) and TE is imposed in estimating the technology and the efficiency levels, not just at the second stage of the analysis (Kumbhakar et al., 1991; Wang and Schmidt, 2002).

In our case, the one-step estimation of TE and its determinants allows us to assess the impact of tenure security perceptions on management capabilities while controlling for changes in land, labor and other inputs. Similar approaches have been used to examine the impacts of education, sharecropping, land fragmentation and migration on TE (Kumbhakar et al., 1991; Ahmed et al., 2002; Chen et al., 2009; Tan et al., 2010).

\section{Data set and choice of variables}

\subsection{Data set}

This study uses data from a farm household survey that was held in Minle County, Zhangye City, Gansu Province in northwest China in May 2010. Minle County can be divided into three agro-ecological zones according to their altitude: (1) between 1,600 and 2,000 m; (2) between 2,000 and 2,200 m; and (3) between 2,200 and 2,600 m. By far the largest zone is the zone 2, 
with 500,000 mu of cultivated land, followed by zones 1 and 3, with 190,000 and 170,000 mu, respectively. ${ }^{4}$ Agricultural production in the zones 1 and 2 generally uses irrigation, while most agricultural production in zone 3 is rainfed.

The survey was held to obtain more insights into the sustainability of land and water use of households living in the area. Collected information refers to the 2009 agricultural season. Household interviews were done in the same 21 villages where a similar survey was held in May 2008. In each of the ten townships in Minle County, 10 per cent of the villages were randomly selected for the survey in May 2008. Eight townships are entirely located inside one of the three zones. The other two townships were divided into two sub-strata (one for each zone) and 10 per cent of the villages were randomly selected in each. This ensures that differences in agricultural conditions between the three zones are adequately reflected in the sample. ${ }^{5}$ Among the 21 villages, five villages are located in agro-ecological zone 1, ten villages in zone 2 and six villages in zone 3. Within each selected village, 15 households were randomly chosen to be interviewed in May 2008. Whenever possible, the same households were interviewed again in May 2010. In cases where the same household could not be found, it was replaced by another, randomly selected, household in the same village.

Although 265 households were interviewed in both years, we cannot exploit the panel nature of the data because questions about land tenure perceptions were asked in the 2010 survey only. Hence, we perform a cross-section analysis for the 315 households interviewed in 2010. As three households had missing information, the total sample size is 312 .

Legal tenure reforms initiated by the Chinese Government since 1998 have been relatively well implemented in the region (Ma et al., 2015). Only 6 per cent of the interviewed households experienced a land reallocation since 1998, with all these households experiencing only one land reallocation since that year. Only 3 per cent of the interviewed households reported that they did not possess a land certificate.

\subsection{Definition of variables}

In addition to agricultural inputs, we include dummy variables representing the different agro-ecological zones in the production frontier. The definition of the variables in the production frontier and their descriptive statistics can be found in online appendix 1, available at http:/ / doi.org/10.1017/S1355770X1600036X. In the TE model, land tenure perceptions, village, household and land characteristics, and regional factors are used as explanatory variables. The definitions of the variables, and their mean values and standard deviations, are presented in table 1.

415 mu equals 1 hectare.

${ }^{5}$ See Wachong Castro et al. (2010) for more details on the research area and data collection. 
Table 1. Definition of variables and their descriptive statistics, technical efficiency model

\begin{tabular}{|c|c|c|c|}
\hline Variable & Definition & Mean & S.D. \\
\hline \multicolumn{4}{|c|}{ Land tenure security variables } \\
\hline $\begin{array}{l}\text { Village perception } \\
\text { on land } \\
\text { reallocations }\end{array}$ & $\begin{array}{l}\text { Mean expectation that no land } \\
\text { reallocations will take place in the } \\
\text { village in the next five years of } \\
\text { the other } 14 \text { sampled households } \\
\text { living in the same village }\end{array}$ & 0.40 & 0.16 \\
\hline $\begin{array}{l}\text { Village perception } \\
\text { on land certificates }\end{array}$ & $\begin{array}{l}\text { Average perception on the } \\
\text { importance of land certificates for } \\
\text { protecting land rights of the other } \\
14 \text { sampled households living in } \\
\text { the same village }\end{array}$ & 4.16 & 0.31 \\
\hline \multicolumn{4}{|l|}{ Village characteristics } \\
\hline Distance to town & $\begin{array}{l}\text { Average distance from the village to } \\
\text { the nearest town seat }(\mathrm{km})\end{array}$ & 5.21 & 4.62 \\
\hline \multicolumn{4}{|c|}{ Household characteristics } \\
\hline Age & Age of the household head (years) & 46.31 & 10.11 \\
\hline Education & $\begin{array}{l}\text { Years of formal education of the } \\
\text { household head (years) }\end{array}$ & 7.55 & 3.46 \\
\hline Wealth & $\begin{array}{l}\text { Value of agricultural devices, } \\
\text { livestock, electronic instruments, } \\
\text { house, furniture and } \\
\text { transportation vehicle (yuan) }\end{array}$ & 62,966 & 64,807 \\
\hline Female ratio & $\begin{array}{l}\text { Ratio of female workers to all } \\
\text { workers in a household }\end{array}$ & 0.46 & 0.15 \\
\hline \multicolumn{4}{|l|}{ Land characteristics } \\
\hline Number of plots & Total number of plots cultivated & 14.60 & 8.49 \\
\hline Land fertility & $\begin{array}{l}\text { Respondent's subjective evaluation } \\
\text { of land fertility, ranging from } \\
1 \text { (= poor ) to } 3 \text { (= good) }\end{array}$ & 2.48 & 0.55 \\
\hline Land slope & $\begin{array}{l}\text { Respondent's subjective evaluation } \\
\text { of land slope of each plot, either } \\
1 \text { (= plain) or } 2 \text { (= sloping), } \\
\text { weighted by plot size }\end{array}$ & 1.06 & 0.19 \\
\hline Land area & Total land area cultivated $(\mathrm{mu})$ & 19.83 & 12.77 \\
\hline \multicolumn{4}{|l|}{ Regional characteristics } \\
\hline Tongziba dummy & $\begin{array}{l}1=\text { farmer resides in Tongziba } \\
\text { irrigation district; } 0=\text { otherwise }\end{array}$ & 0.29 & 0.45 \\
\hline Hongshuihe dummy & $\begin{array}{l}1=\text { farmer resides in Hongshuihe } \\
\text { irrigation district; } 0=\text { otherwise }\end{array}$ & 0.33 & 0.47 \\
\hline Haichaoba dummy & $\begin{array}{l}1 \text { = farmer resides in Haichaoba } \\
\text { irrigation district; } 0=\text { otherwise }\end{array}$ & 0.10 & 0.30 \\
\hline Daduma dummy & $\begin{array}{l}1 \text { = farmer resides in Daduma } \\
\text { irrigation district; } 0=\text { otherwise }\end{array}$ & 0.14 & 0.35 \\
\hline
\end{tabular}

Source: Household survey.

Following Ma et al. (2016), household land tenure security perceptions are measured by expectations with respect to (the absence of) land reallocations in the near future and by the perceived importance of land certificates 
in protecting land rights. ${ }^{6}$ Expectations on future land reallocations take the value 1 if a household does not expect a land reallocation within five years and equal 0 if the household expects a reallocation to occur within five years or does not have an idea. Only 40 per cent of the interviewed households do not expect a land reallocation within the next five years. Hence, household perceptions on the absence of land reallocations are still low even though legal tenure reforms that virtually ban land reallocations have been relatively well implemented in the region. Land certificate perceptions reflect household assessments of the significance of land certificates for protecting land rights. It is measured on a scale of 1 (= not important) to 5 (= very important). Its mean value equals 4.16 , indicating that households attach much weight to land certificates.

The two measures are meant to represent different dimensions of tenure security. Land certificates intend to provide protection against land expropriation and against tenants who are unwilling to return rented land. However, they do not protect against land reallocations much, as they specify the quantity of land that a household is allowed to cultivate but do not include a map showing the location of the land. Four boundaries of each plot should formally be specified in a land certificate, but in practice the information about boundaries is rather vague in many regions, including our research area. ${ }^{7}$ Only when a household's land size is reduced in response to demographic changes, for example when a household has one or more migrants, may land certificates provide adequate protection during land reallocations. But social pressure within a village may prevent households from using certificates for this purpose. Land reallocations within a village affect in particular the location of the land assigned to households. Such changes in location can be an important aspect of tenure (in)security, against which land certificates provide insufficient protection. Hence the two measures can be considered as two separate dimensions of tenure security. ${ }^{8}$

It should be noted that household decisions on migration and land rentals may affect land tenure security perceptions. Households that rent out land and temporally migrate to urban areas are more likely to experience land reallocations or land expropriations, and therefore to perceive lower tenure security (Mullan et al., 2011; Ma et al., 2016). Hence, reverse causality may bias the estimation results. Following Mullan et al. (2011), we use mean village-level land tenure security perceptions, defined as the average tenure security perceptions of the other 14 sampled households

${ }^{6}$ Household expectations and perceptions are derived mainly from the responses of household heads. In a few cases where the household head was living and working elsewhere at the time of the survey, other family members who understand household decisions well were interviewed. We assume that the perceptions of those respondents reflect household heads' perceptions.

7 An important goal of the New Round of Rural Land Ownership Registration Certification Work initiated by the central government in 2013 is to specify the clear boundaries of each plot contracted by a household.

8 The correlation coefficient between the two tenure security variables equals 0.15 . See also figure A1 in online appendix 3. 
within the same village, as proxy variables to minimize the potential endogeneity bias. Because households living in the same village face more or less similar risks of land reallocation or expropriation by village leaders or local governments, the village-level average is likely to be a close proxy of individual household tenure security perceptions. Yet, the use of villagelevel averages may introduce measurement errors. ${ }^{9}$ As a robustness check, we also apply an instrumental variables approach in which village-level averages are used to predict individual tenure security perceptions.

The two tenure security perception dimensions are expected to have divergent impacts on land renting and migration, and thus have different effects on TE. Land certificates provide protection against all types of land expropriation, i.e., against land requisitioning for urban development, infrastructure construction or other purposes, against tenants refusing to return rented land, and possibly also against land expropriations by the village leader in response to demographic changes. Well-functioning land certificates may therefore provide a stronger incentive for participating in land rental markets than absence of land reallocations. In addition, households possessing land certificates are more likely to receive appropriate compensation payments in cases where land is expropriated. These payments may, for example, be used to cover the initial costs of migration. Hence, land certificates may stimulate migration while bans on land reallocations may reduce migration in villages where land rental markets have not developed (Ma et al., 2016).

Village characteristics are represented by the distance from the village to the nearest town seat. The larger the distance from the village to the town seat, the lower the access to markets and the lower the incentive to engage in market production. On the other hand, households in relatively remote villages usually rely more on agricultural income for their livelihoods and thus may have a higher agricultural ability. So the expected effect of the distance between the village and the town seat on TE is ambiguous.

Household characteristics that may affect TE include age and education of the household head, household wealth and female ratio. Age of the household head is used as a proxy for the household's farming experience. Its effect on TE is ambiguous, depending on whether older farmers are more experienced or more likely to stick to farming traditions and less likely to adopt new technologies (Feng, 2008). Education of the household head is used as a proxy for farm management skills. TE is expected to increase with education as education increases the household's ability to utilize existing technologies and make better farm management decisions. Household wealth is an indicator of the economic status of the household within the village. On the one hand, households with more wealth are expected to face fewer obstacles in agricultural production, as they have

9 As village leader decisions play an important role in shaping individual household tenure security perceptions, average village-level perceptions are likely to be appropriate proxies for individual tenure security perceptions. They do not capture, however, household characteristics that cause heterogeneity in perceptions within the same village. 
more resources available for paying fixed costs and for obtaining the information needed to adopt new technologies; on the other hand, they are expected to spend more time on leisure or off-farm employment. So the expected effect of household wealth on TE is ambiguous. Female ratio is defined as the ratio of female workers to all workers. It is meant to capture the difference in TE between female and male workers; its coefficient can have either a positive or negative sign.

Land characteristics in the model include number of plots, land fertility, land slope and land area. Land fragmentation, as measured by the number of plots, can have either negative or positive effects on TE (see, for example, Chen et al., 2009; Tan et al., 2010). On the one hand, given the total land area, farms with more plots need more labor time for travelling, may be more difficult to manage and to use machinery, and may use a larger share of the land for boundaries. On the other hand, more plots can enable households to optimize their labor allocation over different crop species and seasons, especially when the market for agricultural labor is absent or faces high transaction costs. The average number of plots per household is 14.6 in our research area, which is much higher than the average of 5.0 plots for west China as a whole (derived from RFOO, 2010). The average area per plot is $1.36 \mathrm{mu}$; it only slightly exceeds the average value of $1.21 \mathrm{mu}$ for west China (RFOO, 2010). Land fertility and land slope are used as indicators of land quality. They are measured by asking the respondent about the fertility on a scale from 1 (poor) to 3 (good) and the slope $(1=$ plain, $2=$ sloping) of plot(s), and then calculating the weighted average using plot sizes as weights. The mean land fertility value equals 2.48 , indicating that fertility is judged intermediate to good. Most land is flat in the research area, as evidenced by the mean slope value of 1.06. As most land in the region is irrigated, farmers regularly invest in land levelling (Ma et al., 2013). Land fertility is expected to impact positively on TE, while land slope is expected to impact negatively on TE. Moreover, following Reddy (2002), we include total cultivated land area as an additional explanatory variable to examine whether small farmers are more efficient than large farmers.

Finally, four dummy variables are introduced for four of the five irrigation districts to which the interviewed households belong. These dummies are meant to control for major unobserved differences between irrigation districts in factors such as irrigation infrastructure and water availability which may affect water losses and the timing of water availability and thus affect TE.

\section{Estimation results}

\subsection{Results}

The maximum likelihood estimates of the parameters in the production frontier and the corresponding estimated input-output elasticities of the variables in the production frontier are reported and discussed in online appendix 1 . The corresponding TE estimates range from 0.18 to 0.97 for the households in our sample, and equal 0.82 on average. In other words, the interviewed farmers obtain on average 82 per cent of the potential output that can be obtained with the current mixture of production inputs. This 
Table 2. Estimation results for technical efficiency model, maximum likelihood ${ }^{\text {a }}$

\begin{tabular}{lccr}
\hline Explanatory variable & Coefficient & Elasticities $^{\mathrm{b}}$ & t-ratio \\
\hline Constant & $9.940^{* * *}$ & - & 3.596 \\
Village perception on land reallocations & $2.671^{* * *}$ & $1.303^{* * *}$ & 4.189 \\
Village perception on land certificates & $-1.323^{* * *}$ & $-6.712^{* * *}$ & -2.977 \\
Age & $0.010^{*}$ & $0.565^{*}$ & 1.624 \\
Education & $0.060^{* *}$ & $0.552^{* *}$ & 2.867 \\
ln(Wealth) & $-0.423^{* * *}$ & $-5.700^{* * *}$ & -5.362 \\
Female ratio & $0.745^{*}$ & $0.418^{*}$ & 1.405 \\
ln(Number of plots) & $0.532^{* *}$ & $1.739^{* *}$ & 2.917 \\
Land fertility & 0.136 & 0.411 & 1.248 \\
Land slope & 0.353 & 0.456 & 0.864 \\
ln(Land) & $-0.900^{* * *}$ & $-3.279^{* * *}$ & -4.852 \\
Distance to town & -0.005 & -0.032 & -0.216 \\
Tongziba dummy & -0.436 & -0.154 & -0.989 \\
Hongshuihe dummy & $-0.734^{*}$ & $-0.295^{*}$ & -1.691 \\
Haichaoba dummy & $-1.805^{* * *}$ & $-0.220^{* * *}$ & -2.964 \\
Daduma dummy & $-1.486^{* * *}$ & $-0.254^{* * *}$ & -3.077 \\
Observations & 312 & & \\
Log likelihood function & -66.56 & & \\
\hline
\end{tabular}

Notes: $*, * *$, and $* * *$ indicate statistical significance at $10 \%, 5 \%$ and $1 \%$ levels, respectively. ${ }^{a}$ Estimated together with the frontier function in a single stage procedure using Frontier 4.1 software package. ${ }^{b}$ Elasticities are evaluated at mean values.

average TE is slightly larger than the estimate (0.80) obtained by Chen et al. (2009) for farmers in Hebei and Shanxi Provinces during the period 19951999. It is also slightly larger than the value of 0.80 (one-season rice), but lower than the values of 0.89 (late rice) and 0.91 (early rice), estimated by Tan et al. (2010) for three villages in Jiangxi Province in the year 2000.

Actual TE has a larger variation in the sample than predicted TE (see figure A2 in online appendix 3). Predicted values of TE are close to actual TE for households with actual TE exceeding 0.6. These households account for 92 per cent of the whole sample. The model has more problems with predicting low values of TE. Predicted TE generally exceeds actual TE for households with actual TE below 0.6.

As regards the factors explaining observed differences in TE between farmers, the regressions results for the two tenure security variables (table 2) show that expectations regarding the absence of land reallocations have a significant positive impact on the level of $\mathrm{TE}^{10}{ }^{10}$ while the importance attached to land certificates has a significant negative impact.

${ }^{10}$ We performed two additional regression analyses with those who have no idea whether or not to expect land reallocations within five years (i) excluded from the sample and (ii) added to the ones that do not expect a land reallocation within five years. The results are very similar to those presented in table 2 and do not affect 
The estimated elasticities, evaluated at mean values, equal 1.30 and -6.71 , respectively. This finding indicates that household perceptions about land tenure security contribute significantly to the TE levels observed in the research area, with households that expect no land reallocations in the near future having higher TE and households that attach greater importance to land certificates in protecting their land rights having lower TE. We will discuss this finding in more detail in section 5.3. It should be noted that the effects of each tenure security variable are conditional on given values of the other tenure security variable. Unconditional effects are discussed in section 5.2 .

As for the control variables, we find that distance from the village to the nearest town seat has an insignificant impact on TE. The age of household head has a positive impact on TE, suggesting that experience plays an important role in the TE of crop production. The education of the household head positively impacts on TE, as expected. Family wealth has a significant negative impact on TE, suggesting that more wealthy farmers manage their farms in a less efficient way than poorer farmers do. The positive coefficient of the female ratio suggests that female workers have higher TE in crop production than male workers in our research area. Land fragmentation, measured by the number of plots on a farm, is found to have a significant positive effect on TE. This finding is consistent with those of Sherlund et al. (2002) for Côte d'Ivoire and Tan et al. (2010) for Jiangxi Province in China. We also find that land area has a statistically significant negative effect on TE, indicating that small farmers are more efficient than large farmers in the research area. One surprising finding is that the two variables representing land quality, land fertility and land slope do not have a significant impact on TE. One possible reason is that we use farmers' opinions about land fertility and land slopes as indicators of land quality instead of objective measures.

\subsection{Robustness}

As a first robustness check, we estimate the impact of land tenure security on TFP using a production function. Following recent studies on land tenure and agricultural productivity (see, for example, Chand and Yala, 2009; Deininger et al., 2014), we use a Cobb-Douglas specification, ${ }^{11}$ and obtain the following estimable form:

$$
\ln \left(Q_{i}\right)=d_{0}+d_{1} M_{i}+\sum_{j=1}^{n} \alpha_{j} \ln \left(X_{j i}\right)+\varepsilon_{i},
$$

where $Q_{i}$ is the level of output of the $i^{\text {th }}$ household; $X_{j i}$ denotes the $j^{\text {th }}$ input of the $i^{\text {th }}$ household, and $\alpha_{j}$ is the input elasticity of input $j ; n$

the main conclusions obtained from the analyses. The results can be obtained on request from the first author.

${ }^{11}$ When we apply a translog specification, we obtain mean variance inflation factors (VIF) that range up to 500 while the total number of explanatory variables increases to 51. As drawing sensible conclusions from such an analysis becomes rather tedious, we use a Cobb-Douglas function instead. 
denotes the number of inputs and $\varepsilon_{i}$ represents a random disturbance term. In addition to the two land tenure security variables, we include the village, household, land and regional characteristics specified in table 1 as explanatory variables in the vector $M_{i} . d_{0}$ and $d_{1}$ are unknown coefficients. Equation (3) is estimated by using ordinary least squares (OLS).

Table A4 in online appendix 2 reports the regression results for the agricultural production function. The results for the two tenure security perception variables are similar to those obtained for the TE model, although the $t$-ratios have somewhat lower values. Expectations on the absence of land reallocations have a significant positive impact, while the importance attached to land certificates has a significant negative impact.

Another issue that should be taken into account is the potential measurement error when using village-level average tenure security perceptions as proxies of individual tenure security perceptions. As a second robustness check we use the village-level average tenure security perceptions as instruments to predict the values of individual tenure security perceptions. Its purpose is to reduce potential measurement errors of using the village-level average as a proxy of individual tenure security perceptions and to account for potential endogeneity of individual tenure security perceptions. In the first step, we regress individual tenure security perceptions on individual characteristics, land endowment as well as village-level average tenure security perceptions. In the second stage, the resulting predicted values of individual tenure security perceptions are introduced into equation (2). Equations (1) and (2) are estimated using a one-step procedure.

Table A5 in online appendix 2 reports the regression results for the stochastic production frontier using the instrumental variables (IV) method, table A6 presents the resulting input-output elasticities, and table A7 reports the results for the TE equation. We find that the null hypothesis that all variables are exogenous in the model is rejected at a 5 per cent testing level (table A7, last row). Hence, reverse causality may indeed bias the estimation results when individual tenure security variables are used in the model. The results for the two tenure security variables support the main conclusion drawn from the basic model that TE is affected positively by tenure security derived from expectations that no land reallocations will take place and negatively by the importance attached to land certificates in protecting land rights. The coefficients for these two tenure security variables (table A7) again differ significantly from zero, but the estimated coefficient and $t$-ratio for the land certificates variable are much smaller than they are in our basic model (see table 2).

As a third robustness check, we estimated the impact of tenure security perceptions on TFP instead of TE, using the IV method. The results, presented in table A8, provide additional support for the main conclusions that we draw from the basic model.

Finally, we ran regressions with each tenure security variable included individually. As discussed in section 4.2, the two tenure security variables represent two different, almost fully exclusive, dimensions of tenure security. Yet, they may not be completely independent from each other as issuing of land certificates and bans on land reallocations both reduce the 
probability of land expropriation by village leaders through land reallocations. The regression results are presented in tables A9 and A10. Again we find that the land reallocations variable has a significant positive effect on TE while the land certificates variable has a significant negative effect. The corresponding elasticities, which now represent the unconditional effects of each tenure security variable, are somewhat smaller in absolute size than the conditional elasticities estimated from the full model: 1.000 as compared to 1.303 for the land reallocations variable, and -5.066 as compared to -6.712 for the land certificates variable.

\subsection{Causal mechanisms}

Our findings indicate that expectations that no land reallocations will take place in the near future positively affect TE, while the importance attached to land certificates in protecting land rights negatively affects TE. Because variable inputs and land investment (land quality) are control variables in both models, the observed effects can be interpreted as the net results of a positive land market effect and a generally negative migration effect (see figure 1). The relative impact of these two counteracting effects depends on the functioning of land and labor markets.

Empirical evidence of the existence of land rental market and migration effects, based on the same data set as for Minle County in Gansu Province, can be found in Ma (2013: ch. 5) and Ma et al. (2016), respectively. Estimation results of Probit models for household participation in the land rental market and in rural-urban migration in these two studies provide evidence that the importance attached to land certificates in protecting land rights positively affects both the probability of renting land and the probability that at least one of the household members has migrated. Expectations about the absence of land reallocations in the near future, on the other hand, do not have a significant impact on land rentals, and are found to have a significant negative impact on rural-urban migration. Households that expect no land reallocations are more likely to make investments in the land, because they can hold onto the same piece of land, and therefore spend more time working on the land (the so-called 'asset-enhancing' negative effect of tenure security on migration). These findings are consistent with our interpretation of land certificates providing protection against different types of land expropriation and the absence of land reallocations providing protection in particular against changes in the location of land assigned to households (see section 4.2). ${ }^{12}$

12 Deininger et al. (2014: 508) consider land certificates as an institutional arrangement that improves land transferability but leaves tenure security unchanged, while the absence of land reallocations is expected to affect both land transferability and tenure security. The descriptive statistics for the land certificate variable in our analysis show that household perceptions of the importance of land certificates for protecting land rights do vary between households (see table 1). In this study we therefore interpret land certificates as an institutional arrangement which affects tenure security by protecting against land expropriation and which affects land transferability as well. 
Major market imperfections exist in the land rental market and labor market in the research area of this study. The land rental market has developed on a limited scale and is highly segmented. Results of our household survey show that 15 per cent of the households rented in land in 2009. The average rented-in land area was equal to 9.3 per cent of the average contracted land allocated to renting households. More than 85 per cent of the land transfers were between kinship, and only around 40 per cent of the rental contracts were in writing, according to the interviewed tenants. The duration of the land renting was not specified in 88 per cent of the contracts. The labor market in our research area is characterized by short duration migration of individuals, leading to a large share of households involved in part-time farming. The household survey results show that 51 per cent of the households had at least one member who migrated in 2009. Among those households with migrants, on average 1.41 members per household migrated and spent on average 6.84 months outside their county in 2009. Slightly more than 90 per cent of these households participated in (part-time) farming.

Hence, we find evidence for our research area that (household perceptions of) tenure security provided by land certificates stimulates temporary migration by individuals, and thereby encourages part-time farming with relatively low TE. The renting out of land by households with migrants only partly compensates for this negative effect, because land rental markets are thin and highly fragmented. Renting land to kinship, as is common practice in the research area, may not contribute much to increasing TE.

For (household perceptions of) tenure security provided by the absence of land reallocations in the near future, on the other hand, we find that it reduces migration and thereby discourages part-time farming with relatively low TE. The migration effect therefore becomes positive. Moreover, expectations regarding the absence of land reallocations in the near future do not significantly affect household participation in the land rental market. The positive impact on TE of expectations regarding the absence of land reallocations can therefore be interpreted as the net effect of a positive migration effect and an insignificant land market effect.

\subsection{Environmental implications}

The research area of this study, Minle County in Zhangye City, is located in the middle reaches of the Heihe River basin. The Heihe River is an inland river that originates in the Qilianshan mountains (mainly located in Qinghai Province), flows through Zhangye City in Gansu Province and ends in the (East and West) Juyanhai Lake in Inner Mongolia. Zhangye City is an oasis with a dry climate and plenty of sunshine. The irrigation water available from the reservoirs in the mountains and its fertile soils have made this area very suitable for agriculture.

Since the 1960s, water resources discharged from the middle reaches to the lower reaches of the Heihe River basin significantly decreased due to overexploitation for agricultural use in Zhangye City. It led to declining groundwater levels, worsening water quality, reduced vegetation and severe desertification in the area surrounding Juyanhai Lake and transformed it into one of China's 'sandstorm cradles' (Guo et al., 2009). 
At the beginning of the new century, the Ministry of Water Resources initiated a pilot project called 'Building a Water-saving Society in Zhangye City' (Zhang et al., 2013). The pilot project was the first water saving pilot project in China. Its main purpose is to test potential measures to encourage water savings at the local level and find out what works and what does not work, so that successful aspects can be scaled up across the country. Measures taken include engineering measures as well economic incentives, like tradable water use rights, aimed at stimulating a more efficient use of irrigation water. As a result of the pilot project, more water is flowing again into Juyanhai Lake and the ecosystem around the lake is slowly recovering over recent years.

The findings of our study indicate that measures that improve tenure security perceived by rural households may also play a significant role in stimulating a more efficient use of irrigation water in the region. In particular, households that do not expect land reallocations to take place in the near future are expected to have a higher level of TE because they participate less in temporary migration. As a result, the same agricultural output levels can be reached by using lower quantities of water and other inputs. On the other hand, households attaching greater importance to land certificates in protecting land rights tend to have lower levels of TE due to prevailing factor market imperfections. The issuance of land certificates will therefore only contribute to more efficient use of water and other inputs in agricultural production if it is combined with measures aimed at removing existing obstacles facing land rental market development and permanent migration to urban areas. We will come back to this in the next section.

It should be noted that we consider land quality and levels of input use as given in this study (see figure 1). Previous studies have shown that changes in tenure security may also affect soil conservation investments, water use, fertilizer use, and the use of other inputs that may cause environmental pollution. The resource conservation and pollution effects of these input and investment decisions may either counterbalance or strengthen the environmental effects of changes in TE. An assessment of the full environmental effects of changing tenure security perceptions is, however, beyond the scope of our study.

\section{Conclusion}

An important element of agriculture-based growth policies in China and many other parts of the world is promoting the productive and efficient use of land and water resources to meet present and future demands for agricultural products, while ensuring the long-term sustainability of the land and water quantity and quality. Increases in TE are crucial elements of such policies as they make it possible to obtain higher output with the same amounts, or even lower amounts, of land, water and other inputs used in production. This paper examines the role of land tenure security as perceived by rural households in TE in northwest China. By controlling for land investments and input use in the empirical analysis, we focus on two - potentially offsetting - effects of improved land tenure security on 
agricultural production, namely the positive land rental market effect and the, generally negative, migration effect. When land rental and labor markets function well, the net impact of these two effects on TE will be positive. But when these markets are imperfect or incomplete, the net effect may well be negative.

Based on data collected through a household survey in Minle County, Gansu Province, we find that the (perceived) tenure security provided by land certificates stimulates temporary migration by individuals, and thereby encourages part-time farming with relatively low TE. The renting out of land by households with migrant members can only partly make up for this negative effect, because land rental markets are thin and highly fragmented. The provision of land certificates to rural households therefore has a negative impact on TE under the prevailing factor market imperfections in the region. For tenure security provided by the expected absence of land reallocations in the near future, on the other hand, we find that it reduces temporary migration by individuals and thereby contributes to higher TE.

By removing existing obstacles to land rental market development and rural-urban migration, the negative impact of land tenure security derived from land certificates on TE may change into a positive effect. Measures that may be taken in this respect include increased reliance on the rule of law in settling land conflicts, adequate information provision to rural households about the importance of land certificates for pursuing rights in land conflicts, further development and expansion of the rural social insurance systems in order to reduce farmers' reliance on rural land as a means of social insurance, and equal treatment of urban residents and migrants in urban health, education and social insurance systems. All these measures can be expected to stimulate the functioning of land and labor markets, and thereby strengthen the impact of recent policy reforms aimed at improving land tenure security in rural China on TE in agricultural production.

Although our study is limited to just one county in northwest China, the examined issues are likely to be of relevance to other parts of rural China characterized by imperfect and incomplete land rental and labor markets. The insights gained may also be useful for a wider range of developing countries (e.g., Ethiopia, Vietnam) with similar rural land tenure systems and underdeveloped land and labor markets. The main lessons to be learned from our study are that a focus on formal land rights in explaining TE and agricultural productivity is likely to be too narrow, and that improved tenure security derived from land certificates may in fact lower TE due to the migration effect when land rental and labor markets are underdeveloped.

In our study we use cross-sectional data for deriving empirical estimates. It cannot be ignored that household and land characteristics that are either unmeasured or not measured adequately affect both the dependent variable and one or more of the explanatory variables in our analysis. The robustness of the main conclusions derived from our study should therefore preferably be checked through the use of panel data analysis (e.g., using household fixed effect models) in future research. 
Another issue that may receive more attention in follow-up research is household time allocation to migration and crop production during different parts of the year. By collecting and analyzing weekly or monthly household data on labor input into crop production and time spent on migration, the extent to which temporary migration and crop production compete for labor resources throughout the year can be examined in a more direct way and the results may be compared with the indirect evidence that we provide in this paper.

\section{Supplementary material and methods}

To view supplementary material for this article, please visit https://doi. org/10.1017/S1355770X1600036X.

\section{References}

Ahmed, M.M., B. Gebremedhin, S. Benin, and S. Ehui (2002), 'Measurement and sources of technical efficiency of land tenure contracts in Ethiopia', Environment and Development Economics 7(3): 507-527.

Besley, T. (1995), 'Property rights and investment incentives: theory and evidence from Ghana', Journal of Political Economy 103(5): 903-937.

Brasselle, A.S., F. Gaspart, and J.P. Platteau (2002), 'Land tenure security and investment incentives: puzzling evidence from Burkina Faso', Journal of Development Economics 67(2): 373-418.

Chand, S. and C. Yala (2009), 'Land tenure and productivity: farm-level evidence from Papua New Guinea', Land Economics 85(3): 442-453.

Chen, P., M. Yu, C. Chang, and S. Hsu (2008), 'Total factor productivity growth in China's agricultural sector', China Economic Review 19: 580-593.

Chen, Z., W.E. Huffman, and S. Rozelle (2009), 'Farm technology and technical efficiency: evidence from four regions in China', China Economic Review 20(2): 153-161.

Chernina, E., P. Dower, and A. Markevich (2014), 'Property rights, land liquidity and internal migration', Journal of Development Economics 110: 191-215.

Deininger, K. and S. Jin (2006), 'Tenure security and land-related investment: evidence from Ethiopia', European Economic Review 50(5): 1245-1277.

Deininger, K. and E. Zegarra (2003), 'Determinants and impacts of rural land market activity: evidence from Nicaragua' World Development 31(8): 1385-1404.

Deininger, K., D.A. Ali, and T. Yamano (2008), 'Legal knowledge and economic development: the case of land rights in Uganda', Land Economics 84(4): 593-619.

Deininger, K., S. Jin, F. Xia, and J. Huang (2014), 'Moving off the farm: land institutions to facilitate structural transformation and agricultural productivity growth in China', World Development 59: 505-520.

Feder, G. (1988), Land Policies and Farm Productivity in Thailand, Baltimore, MD: Johns Hopkins University Press.

Feng, S. (2008), 'Land rental, off-farm employment and technical efficiency of farm households in Jiangxi Province, China', NJAS-Wageningen Journal of Life Sciences 55(4): 363-378.

Feng, S., N. Heerink, R. Ruben, and F. Qu (2010), 'Land rental market, off-farm employment and agricultural production in Southeast China: a plot-level case study', China Economic Review 21(4): 598-606.

Gavian, S. and S. Ehui (1999), 'Measuring the production efficiency of alternative land tenure contracts in a mixed crop-livestock system in Ethiopia', Agricultural Economics 20(1): 37-49. 
Guo, Q., Q. Feng, and J. Li (2009), 'Environmental changes after ecological water conveyance in the lower reaches of Heihe River, northwest China', Environmental Geology 58(7): 1387-1396.

Jacoby, H.G., G. Li, and S. Rozelle (2002), 'Hazards of expropriation: tenure insecurity and investment in rural China', American Economic Review 92(5): 1420-1447.

Kumbhakar, S.C., S. Ghosh, and J.T. McGuckin (1991), 'A generalized production frontier approach for estimating determinants of inefficiency in US dairy farms', Journal of Business \& Economic Statistics 9(3): 279-286.

Ma, X. (2013), 'Does tenure security matter? Rural household responses to land tenure reforms in northwest China', $\mathrm{PhD}$ thesis, Wageningen University, [Available at] http:/ /library.wur.nl/WebQuery/clc/2044163.

Ma, X., N. Heerink, E. van Ierland, M. van den Berg, and X. Shi (2013), ‘Land tenure security and land investments in Northwest China', China Agricultural Economic Review 5(2): 281-307.

Ma, X., N. Heerink, S. Feng, and X. Shi (2015), 'Farmland tenure in China: comparing legal, actual and perceived security', Land Use Policy 42: 293-306.

Ma, X., N. Heerink, E. van Ierland, and X. Shi (2016), 'Land tenure insecurity and rural-urban migration in rural China', Papers in Regional Science 95(2): 383-406.

Mullan, K., P. Grosjean, and A. Kontoleon (2011), 'Land tenure arrangements and rural-urban migration in China', World Development 39(1): 123-133.

Pender, J., E. Nkonya, P. Jagger, D. Sserunkuuma, and H. Ssali (2004), 'Strategies to increase agricultural productivity and reduce land degradation: evidence from Uganda', Agricultural Economics 31(3): 181-195.

Place, F. (2009), 'Land tenure and agricultural productivity in Africa: a comparative analysis of the economics literature and recent policy strategies and reforms', World Development 37(8): 1326-1336.

Qu, F., A. Kuyvenhoven, X. Shi, and N. Heerink (2011), 'Sustainable natural resource use in rural China: recent trends and policies', China Economic Review 22(4): 444-460.

Reddy, M. (2002), 'Implication of tenancy status on productivity and efficiency: evidence from Fiji', Sri Lankan Journal of Agricultural Economics 4(1): 19-37.

Rozelle, S., J.E. Taylor, and A. de Brauw (1999), 'Migration, remittances and agricultural productivity in China', American Economic Revieww 89(2): 287-291.

RFOO (Rural Fixed Observation Office), Central Policy Research Division and Agricultural Ministry, P.R. China (2010), National Rural Social Economic Survey Data Collection (2000-2009), Beijing: China Agricultural Press [in Chinese].

Sherlund, S.M., C.B. Barrett, and A.A. Adesina (2002), 'Smallholder technical efficiency controlling for environmental production conditions', Journal of Development Economics 69(1): 85-101.

Shi, X., N. Heerink, and F. Qu (2011), 'Does off-farm employment contribute to agriculture-based environmental pollution? New insights from a village-level analysis in Jiangxi Province, China', China Economic Review 22(4): 524-533.

Tan, S., N. Heerink, A. Kuyvenhoven, and F. Qu (2010), 'Impact of land fragmentation on rice producers' technical efficiency in South-East China', NJASWageningen Journal of Life Sciences 57(2): 117-123.

Wachong Castro, V., N. Heerink, X. Shi, and W. Qu (2010), 'Water savings through off-farm employment?', China Agricultural Economic Review 2(2): 167-184.

Wang, H.J. and P. Schmidt (2002), 'One-step and two-step estimation of the effects of exogenous variables on technical efficiency levels', Journal of Productivity Analysis 18(2): 129-144.

Whalley, J. and S. Zhang (2007), 'A numerical simulation analysis of (Hukou) labor mobility restrictions in China', Journal of Development Economics 83(2): 392-410. 
World Bank (2007), World Development Report 2008: Agriculture for Development, Washington, DC: World Bank.

Zhang, L., N. Heerink, L. Dries, and X. Shi (2013), 'Water users associations and irrigation water productivity in northern China', Ecological Economics 95: 12-136.

Zhang, Y., X. Wang, T. Glauben, and B. Brümmer (2011), 'The impact of land reallocation on technical efficiency: evidence from China', Agricultural Economics 42(4): 495-507. 